\title{
Питання психології
}

Вахоцька I. О., кандидат психологічних наук, доцент, доиент кафедри психології Уманського державного педагогічного університету ім. Павла Тичини

\section{ВІДНОВЛЕННЯ ПСИХІЧНОЇ СТІЙКОСТІ КОМБАТАНТІВ ЯК ВАЖЛИВА УМОВА ЗБЕРЕЖЕННЯ ЇХНЬОГО ПСИХІЧНОГО ЗДОРОВ Я}

У статті розкрито психологічний зміст прочесу відновлення психічної стійкості комбатантів як важливу умову збереження їхнього психічного здоров'я та ефективного виконання професійних завдань. Зазначається, що у психологічній літературі відновлення є синонімом реабілітації, яка передбачає комплекс заходів, спрямованих на відновлення порушених фуннкиій організму $i$ праиездатності. Низка дослідників розглядають соиіально-психологічну реабілітацію як різновид психологічної допомоги, у тій частині, в якій вона спрямована на відновлення втрачених (порушених) психічних можливостей $і$ здоров'я військовослужбовців. Відновлення психічної стійкості комбатанта - це комплексна система психологічних заходів, спрямована на гармонізацію його внутрішнього стану шляхом особистісних змін у його психічі з метою подолання негативних психічних станів.

Ключові слова: відновлення психічної стійкості, комбатант, психічне здоров'я, соціальнопсихологічна реабілітащія, нервово-психічна напруженість.

В статье раскрыто психологическое содержание прочесса восстановления психической устойчивости комбатантов как важное условие сохранения их психического здоровья $и$ эффективного выполнения профессиональных заданий. Отмечается, что в психологической литературе восстановление является синонимом реабилитащии, которая предусматривает комплекс мероприятий, направленных на возобновление нарушенных функиий организма и работоспособности. Ряд исследователей рассматривают соиіально-психологическую реабилитачию как разновидность психологической помощи, в той части, в которой она направлена на возобновление потерянных (нарушенных) психических возможностей и здоровья военнослужащих. Восстановление психической устойчивости комбатанта - это комплексная система психологических мероприятий, направленная на гармонизацию его внутреннего состосяния путем личностных изменений в его психике с иелью преодоления негативных психических состояний.

Ключевые слова: восстановление психической устойчивости, комбатант, психическое здоровье, соииально-психологическая реабилитачия, нервово-психическая напряженность.

Актуальність дослідження. Психологи дедалі частіше акцентують увагу на негативному впливі бойових дій на психіку їхніх учасників. Зважаючи на те, що більшість комбатантів психологічно нездатні самостійно повернутися до системи соціальних зв'язків і норм мирного життя, виникає потреба у психологічній реабілітації, що спрямована на відновлення їхнього психічного здоров'я. Через вищезазначене дослідження психологічних наслідків таких негативних явищ є вкрай актуальним i має велике практичне значення. Вихідним засадничим положенням такого дослідження має бути те, що успішно справлятися 3 перезавантаженням можуть лише ті, хто володіє необхідними для цього особистісними ресурсами. Тому, на сьогодні, найважливішими завданнями практичних психологів $є$ участь у системі заходів щодо відновлення психічного здоров'я комбатантів в процесі їхньої медико-психологічної реабілітації, на що і спрямована затверджена урядом від 12.07.2017 р. №475-р Концепція Державної цільової програми 3 фізичної, медичної, психологічної реабілітації і соціальної та професійної реадаптації учасників антитерористичної операції на період до 2022 року, яка передбачає створення системи реабілітації учасників АТО, що зможе надавати послуги понад 350000 осіб iз забезпеченням моніторингу їхнього фізичного та психологічного стану, реадаптації у суспільні процеси [1].

Аналіз досліджень та публікацій. Проблема відновлення психічної стійкості комбатантів почала системно досліджуватися в аспекті їхньої реадаптації та реабілітації після другої Світової війни, особливо 3 кінця $70-\mathrm{x}$ років минулого століття. Для розуміння сутності, змісту та структури психологічної реабілітації у науковій літературі виокремлюють декілька підходів, а саме: загально-психологічний (К.Абульханова-Славская, Л.Божович, Б.Братусь, Л.Гребенніков, В.Іванников, 


\section{Питання психології}

Л.Китаєв-Смик, О.Конопкін, Л.Терехова, 3.Фрейд та ін.), який розглядає реабілітацію як відновлення психічної рівноваги i комплексу психічних реакцій, адекватних вимогам навколишнього життєвого середовища; соціально-психологічний А.Анцупов, т.Золотарьова, Дж.Келлі, В.Мясищев, Дж.Роттер, В.Франкл, К.Роджерс та ін.) представники якого підходять до реабілітації як до відновлення системи взаємин пораненого і соціального середовища; військово-психологічний (Р.Абурахманов, В.Березовець, Л.Желєзняк, А.Караяні, В.Мисюра, В.Попов, С.Соловйов, М.Феденко, Дж.Келлі, Б.Колодзін, Дж.Ротор та ін.), який орієнтований на відновлення психічного здоров'я людини після діяльності в екстремальних умовах; медичний (Ю.Александровський, В.Долініна, П.Іванов, М.Кабанов, А.Квасенко, А.Кучеренко, В.Лобзіна, О.Решетнікова та ін.), спрямований на відновлення соматичного здоров'я i працездатності хворих.

Постановка завдання. Аналіз наукового доробку вчених, зусилля яких спрямовані на вивчення процесу відновлення психічної стійкості ветеранів війни у контексті збереження їхнього психічного та професійного здоров'я.

Мета статті - розкрити психологічний зміст процесу відновлення психічної стійкості комбатантів як важливу умову збереження їхнього психічного здоров'я та ефективного виконання професійних завдань.

Виклад основного матеріалу. У психологічній літературі відновлення $€$ синонімом реабілітації (rehabilitation лат. «відновлення»), яка передбачає комплекс заходів, спрямованих на відновлення порушених функцій організму i працездатності. Оскільки реабілітація є більш вживаним у науково-психологічній літературі, тому розглянемо сутність цього поняття. Відновлення психічної стійкості можна розглядами у межах загальнопсихологічного та військово-психологічного підходів. Оскільки перебування військовослужбовців у зоні АТО може призвести до специфічних змін у їхній психіці, тому для відновлення психічної стійкості необхідно розробити систему заходів для відновлення їхньої психічної рівноваги.

Сутність реабілітації може бути глибше зрозумілою $з$ позицій системного підходу, де реабілітація представляє одночасно: мету (відновлення i збереження статусу особистості); процес (що має біопсихологічні та соціальні механізми) i метод підходу до людини, що потребує реабілітації. У дослідженні В.Шевченка і О.Руденка психологічна реабілітація визначається як процес організованого психологічного впливу, спрямованого на допомогу військовослужбовцям у подоланні негативних психологічних наслідків пережитого ними травматичного стресу військової діяльності для забезпечення такого стану психічного здоров'я військовослужбовців, що дозволяє їм достатньо ефективно виконувати бойові i службові завдання [2].

Є.Потапчук, О.Сафін, В.Стасюк розглядають психологічну реабілітацію як систему педагогічних, соціальних заходів, спрямованих на відновлення, корекцію або компенсацію порушених психічних функцій, станів, особистісного і соціального статусу людей, що одержали психічну травму [3-5]. На їхне переконання психологічна реабілітація $\epsilon$ найважливішим елементом відновлення психічної рівноваги i сутність іiі полягає у здійсненні різних впливів через психіку на військовослужбовця 3 врахуванням терапії, профілактики, гігієни і педагогіки. За допомогою психологічних впливів стає можливим знизити рівень нервово-психічної напруженості, швидше відновити втрачену нервову енергію i, тим самим, вплинути на прискорення процесів відновлення в інших органах і системах організму.

Низка дослідників розглядають соціально-психологічну реабілітацію як різновид психологічної допомоги, у тій частині, в якій вона спрямована на відновлення втрачених (порушених) психічних можливостей і здоров'я військовослужбовців [6-8]. 3'ясовано, що психологічна реабілітація може бути складовою соціально-психологічної реадаптації, коли це стосується допомоги людям зі симптомами психічних дисгармоній. Проте вона може бути i самостійною діяльністю, у випадках ії 


\section{Питання психології}

спрямованості на відновлення психічних функцій та особистісних якостей учасників бойових дій, які отримали бойову психічну травму.

У дослідженні В.Лескова, соціальнопсихологічна реабілітація учасників бойових дій $\epsilon$ системою психологічних, психотерапевтичних та психологопедагогічних заходів, що спрямовані на відновлення психічного здоров'я, порушених психічних функцій i станів, особистісного та соціального статусу військовослужбовців, які брали участь у бойових діях. Крім того, психологічну реабілітацію він визначає як специфічний вид психологічної допомоги, що надається військовослужбовцям, які переживають або гострі реакції на стрес, або загострення відтермінованих негативних психологічних наслідків, реакцій та розладів, що зумовлені пережитим психотравмуючим стресом. У іншому варіанті, на думку автора, психологічна реабілітація $\epsilon$ центральною ланкою реабілітаційного процесу i доповнюється медичною реабілітацією або ж лише певною медичною допомогою [9, c. 55].

У дослідженні О.Тімченка психологічна реабілітація після участі в екстремальних подіях у контексті авторської системи психологічного забезпечення визначається як система соціальнопсихологічних, психологічних, психофізіологічних, медико-психологічних, загальнооздоровчих заходів, спрямованих на відновлення, корекцію чи компенсацію порушених психосоматичних функцій, психофізіологічних станів, особистісних властивостей [10]. Завданнями психологічної реабілітації, на їхню думку $є$ психодіагностика станів співробітників 3 метою профілактики розвитку посттравматичного синдрому; забезпечення адаптації після участі в екстремальних подіях; здійснення психологічних корекційно-реабілітаційних заходів; проведення реабілітаційних тренінгів; психологічне консультування співробітників 3 питань відновлення психосоматичного здоров'я.

А.Шевцов зазначає, що важливо під час створення системи реабілітації військових дотримуватись основних базових наукових принципів реабілітології, апробованих практикою, а саме: принципу поліфакторної діяльнісной біопсихосоціальної моделі інвалідності та самого процесу комплексного реабілітування; системносинергетичного принципу реабілітування як комплексного неперервного багатомодального процесу; принципу особистісної спрямованості процесу реабілітування та суб'єктності реабілітовуваного тощо. При цьому він пропонує розглядати сутність моделі реабілітації у тому, щоб досягти таких цілей щодо реабілітованого: відновлення та корекція здоров'я (фізичного, соціального, психічного); соціалізація; соціальна інтеграція; соціальна адаптація; підвищення якості життя; формування стилю незалежного життя; формування способу діяльності за типом «повноцінно функціонуюча людина» [15].

А.Дацковим розглянуто основні етапи психологічної реабілітації: діагностичний оцінка психосоматичного статусу, функціонального, психофізіологічного стану потерпілих, їхніх індивідуальнопсихологічних та індивідуальнопсихофізіологічних адаптивних властивостей, визначення ступеня відхилень від норми у їхніх станах і властивостях; класифікаційний - виокремлення групи осіб 3 ознаками неадаптивних станів та адаптаційних розладів; визначення методів впливу - конкретизація методичного інструментарію загальнооздоровчих, відновлювальних, соціально-психологічних, психологічних і психофізіологічних заходів; корекційний - застосування методів впливу на основі індивідуального підходу до потерпілих; контрольно-оцінний - контроль результативності методів, що застосовуються, та їхня корекція (за потребою). При цьому, специфіка режиму реабілітаційної роботи залежить від рівня i змісту станів і розладів [11].

Загалом, серед напрямків підтримки та підвищення психічної стійкості виокремлюють такі: професійнодіяльнісний; соціально-психологічний; індивідуально-психологічний. Професійнодіяльнісний містить: знання i грамотну експлуатація особистої зброї і спорядження; формування та підтримання навичок ведення бою у різних умовах; професійнопсихологічний відбір i розподіл військовослужбовців за військовими професіями 3 врахуванням їхніх 


\section{Питання психології}

характерологічних особливостей та особистих якостей; облік, контроль і дозування психічного навантаження кожного воїна порівняння з особливостями його військової професії та індивідуальнопсихологічними особливостями; об' єктивна оцінка результатів бойової діяльності кожного військовослужбовця і підрозділів у цілому безпосереднім командуванням і т. п.

До соціально-психологічних можна віднести: постійне і повне інформування особового складу частин і підрозділів про умови та особливості майбутніх бойових дій; формування та згуртування військових розрахунків і підрозділів; правильний підбір, розстановка i комплектування розрахунків і відділень 3 врахуванням індивідуально-психологічних особливостей військовослужбовців; розбір та аналіз причин загибелі військовослужбовців як один із засобів вироблення психологічного настрою на бойові дії i усунення благодушності, самозаспокоєння, халатності і т. п.

До індивідуально-психологічних відносять: знання особистісних особливостей кожного воїна; виховання у військовослужбовців таких якостей як, почуття особистої відповідальності і дисциплінованості, сміливості і рішучості; холоднокровності і розумної ініціативи тощо; конкретна професійна, спеціальна i психологічна підготовка до кожного бою; постійна підтримка досягнутого рівня військово-професійної натренованості; недопущення тривалих перерв у бойовій діяльності; планомірне введення воїнів- новачків у бойову діяльність 3 поступовим збільшенням складності бойових завдань; збереження психічного і фізичного здоров'я шляхом використання методів психічної саморегуляція і корекція психічних станів.

Висновки. Отже, у більшості досліджень трактування поняття реабілітації (відновлення) $€$ достатньо різним, однак сутність залишається незмінною - це система різних заходів, спрямованих на запобігання, відновлення i корекцію психічних станів індивідів. Тому відновлення психічної стійкості комбатанта - це комплексна система психологічних заходів, спрямована на гармонізацію його внутрішнього стану шляхом особистісних змін у його психіці з метою подолання негативних психічних станів. Сутність відновлення психічної стійкості полягає у здійсненні різних впливів на психіку комбатанта, за допомогою яких стає можливим знизити рівень нервово-психічної напруженості і тим самим вплинути на прискорення процесів відновлення організму у цілому.

Перспективами

подальших досліджень у обраному напрямку $\epsilon$ вивчення особистісних чинників, що детермінують процес травматизації i посттравматичної адаптації учасників АТО, зокрема, ролі психічної ригідності у формуванні і розвитку посттравматичного стресового розладу, що обмежує можливість його діагностики, прогнозу, динаміки, i, відповідно, оцінки ефективності психічного і фізичного відновлення комбатантів.

\section{Список використаних джерел}

1. Про схвалення Концепції Державної цільової програми з фізичної, медичної, психологічної реабілітації і соціальної та професійної реадаптації учасників антитерористичної операції на період до 2022 року Розпорядження Кабінету Міністрів України від 12.07.2017 р. №475-р. - Режим доступу http://zakon2.rada.gov.ua/laws/show/475-2017-\%D1\%80

2. Шевченко В.В., Руденко А.А. Психологічна реабілітація військовослужбовців, що перебували в миротворчому контингенті /В.В. Шевченко, А.А. Руденко// Науковий вісник Миколаївського державного університету імені В.О. Сухомлинського. Серія: Психологічні науки. - 2014. - Вип. 2(12). - C. 239-243.

3. Сафін О.Д. Основні підходи до функціонування системи психологічної реабілітації та реадаптації учасників антитерористичної операції /О.Д. Сафін/ Наука і оборона :журнал. - 2016. - №1. - C. 24-30.

4. Потапчук Є.М. Теорія та практика збереження психічного здоров'я військовослужбовців: моногр. / С.М. Потапчук. - Хмельницький: вид-во Національної академії Державної прикордонної служби України, 2004. - 319 с.

5. Стасюк В. Психологічна допомога військовослужбовцям у бойовий та післябойовий період /В.Стасюк// Психологія і суспільство, 2006. - №2. - С. 137-140.

6. Алещенко В.І., Хміляр О.Ф. Психологічна реабілітація військовослужбовців 3 постстресовими психічними розладами /В.І. Алещенко, О.Ф. Хміляр// Навчальний посібник. - Х.: ХУПС, 2005. - 84 с. 


\section{Питання психології}

7. Мась Н.М. Сім`я учасника бойових дій як суб`єкт відновлення його психічного здоров `я /Н.М. Мась// Актуальні дослідження в сучасній вітчизняній екстремальній та кризовій психології: монографія. За заг. ред. В.П. Садкового, О.В. Тімченка. - НУ ЦЗУ. - Х.: ФОП Мезіна В.В., 2017. - С. $383-402$.

8. Хуртенко О.В. Метод психологічного дебрифінгу в комплексній системі соціальнопсихологічної реабілітації учасників АТО /О.В. Хуртенко// Вісник Національного університету оборони України. - № (46). - К., 2015. - С. 333-338.

9. Лесков В.О. Соціально-психологічна реабілітація військово-службовців із районів військових конфліктів : автореф. дис. канд. психол. наук / Валерій Олександрович Лесков. - Хмельницький: Видво НАДПСУ, 2008. - 164 с.

10. Тімченко О.В. Психологічні особливості «виходу 3 війни» військовослужбовців та працівників служби порятунку /О.В. Тімченко/ Особистість як суб'єкт подолання кризових ситуацій: психологічна теорія і практика : монографія / за ред. С.Д. Максименка, С.Б. Кузікової, В.Л. Зливкова. Суми : Вид-во СумДПУ імені А.С. Макаренка. - 2017. - С.201-216.

11. Дацков А.В. Психологічні особливості постекстремальної адаптації учасників антитерористичної операції : дис. канд. психол. наук / Антон Володимирович Дацков. - Національна академія Державної прикордонної служби України імені Богдана Хмельницького. - Хмельницький, 2017. $-212 \mathrm{c}$.

\section{References}

1. Pro cxvalennja Koncepciï Derzhavnoï cil'ovoï programi z fizichnoï, medichnoï, pcixologichnoï reabilitaciï i cocial'noï ta profecijnoï readaptaciï uchacnikiv antiterorictichnoï operaciï na period do 2022 roku Rozporjadzhennja Kabinetu Minictriv Ukraïni vid 12.07.2017 r. №475-r. - Rezhim doctupu http://zakon2.rada.gov.ua/laws/show/475-2017-\%D1\%80

2. Shevchenko V.V., Rudenko A.A. Pcixologichna reabilitacija vijc'kovocluzhbovciv, shho perebuvali v mirotvorchomu kontingenti /V.V. Shevchenko, A.A. Rudenko// Naukovij vicnik Mikolaïvc'kogo derzhavnogo univercitetu imeni V.O. Cuxomlinc'kogo. Cerija: Pcixologichni nauki. - 2014. - Vip. 2(12). - C. 239-243.

3. Cafin O.D. Ocnovni pidxodi do funkcionuvannja cictemi pcixologichnoï reabilitaciï ta readaptaciï uchacnikiv antiterorictichnoï operaciï /O.D. Cafin/ Nauka i oborona :zhurnal. - 2016. - №1. - C. 24-30.

4. Potapchuk E.M. Teorija ta praktika zberezhennja pcixichnogo zdorov'ja vijc'kovocluzhbovciv: monogr. / Є.M. Potapchuk. - Xmel'nic'kij: vid-vo Nacional'noï akademiï Derzhavnoï prikordonnoï cluzhbi Ukraïni, 2004. - $319 \mathrm{c}$.

5. Ctacjuk V. Pcixologichna dopomoga vijc'kovocluzhbovcjam u bojovij ta picljabojovij period /V.Ctacjuk// Pcixologija i cucpil'ctvo, 2006. - №2. - C. 137-140.

6. Aleshhenko V.I., Xmiljar O.F. Pcixologichna reabilitacija vijc'kovocluzhbovciv z poctctrecovimi pcixichnimi rozladami /V.I.Aleshhenko, O.F. Xmiljar// Navchal'nij pocibnik. - X.: XUPC, 2005. - 84 c.

7. Mac' N.M. Cim`ja uchacnika bojovix dij jak cub ‘kt vidnovlennja jogo pcixichnogo zdorov’ja /N.M. Mac'// Aktual'ni doclidzhennja v cuchacnij vitchiznjanij ekctremal'nij ta krizovij pcixologii: monografija. Za zag. red. V.P. Cadkovogo, O.V. Timchenka. - NU CZU. - X.: FOP Mezina V.V., 2017. - C. 383-402.

8. Xurtenko O.V. Metod pcixologichnogo debrifingu v komplekcnij cictemi cocial'no-pcixologichnoï reabilitaciï uchacnikiv ATO /O.V. Xurtenko// Vicnik Nacional'nogo univercitetu oboroni Ukraïni. - №(46). K., 2015. - C. 333-338.

9. Leckov V.O. Cocial'no-pcixologichna reabilitacija vijc'kovo-cluzhbovciv iz rajoniv vijc'kovix konfliktiv : avtoref. dic. kand. pcixol. nauk / Valerij Olekcandrovich Leckov. - Xmel'nic'kij: Vid-vo NADPCU, 2008. - $164 \mathrm{c}$.

10. Timchenko O.V. Pcixologichni ocoblivocti «vixodu z vijni» vijc'kovocluzhbovciv ta pracivnikiv cluzhbi porjatunku /O.V. Timchenko/ Ocobictict' jak cub'ekt podolannja krizovix cituacij: pcixologichna teorija i praktika : monografija / za red. C.D. Makcimenka, C.B. Kuzikovoï, V.L. Zlivkova. - Cumi : Vid-vo CumDPU imeni A.C. Makarenka. - 2017. - C.201-216.

11. Dackov A.V. Pcixologichni ocoblivocti poctekctremal'noï adaptaciï uchacnikiv antiterorictichnoï operaciï : dic. kand. pcixol. nauk / Anton Volodimirovich Dackov. - Nacional'na akademija Derzhavnoï prikordonnoï cluzhbi Ukraïni imeni Bogdana Xmel'nic'kogo. - Xmel'nic'kij, 2017. - 212 c.

\section{SUMMARY \\ Vahotska I., associate Professor in psychological sciences \\ THE RENEWAL OF COMBATANT'S PSYCHICAL FIRMNESS AS IMPORTANT CONDITION OF MAINTENANCE OF THEIR PSYCHICAL HEALTH}

Psychological maintenance of process of proceeding in psychical firmness of combatants as important condition of maintenance of their psychical health and effective implementation of professional tasks is exposed in the article. Marked, that in psychological literature renewal is the synonym of rehabilitation, that 


\section{Питання психології}

envisages the complex of events, broken functions of organism and capacity sent to renewal. Essence of rehabilitation can be deeper clear from positions of approach of the systems, where a rehabilitation presents simultaneously: sweep (renewal and maintenance of status of personality); a process (what has biopsychological and social mechanisms) and method of going are near a man that needs a rehabilitation.

Some of researchers examine a social-psychological rehabilitation as variety of psychological help, in that part in that she is sent to proceeding in the lost (broken) psychical possibilities and health of servicemen. It is found out, that a psychological rehabilitation can be the constituent of social-psychological readaptation, when it touches a help to the people with the symptoms of psychical disharmonies. However she can be and independent activity, in the cases of her orientation on proceeding in psychical functions and personality qualities of participants of battle actions, that got a battle psychical trauma.

Proceeding in psychical firmness of combatant is the complex system of psychological events, sent to harmonization of him internal will become the way of personality changes in his psyche with the aim of overcoming of negative mental conditions. Essence of proceeding in psychical firmness consists in realization of different influences on the psyche of combatant, by means of that becomes possible to bring down the level of neuropsychic tension and to influence the same on the acceleration of processes of proceeding in an organism on the whole.

Among directions of support and increase of psychological firmness distinguish such: professionallyactivitional; social-psychological; individually-psychological. The features of proceeding in psychical firmness of combatants consist in that motion of renewal process of combatants depends on terms, in what of them get after a return from the zone of ATO, creation of positive atmosphere will assist the change of their mental condition; character of the psyche injuring events creates additional barriers during development of corresponding adaptation-subject processes, and the temporal, complete or partial isolation of participants of the battle operating under maintenance of natural social connections will provide the acceleration of renewal period; the psychological informing of combatants in relation to intensification of negative displays of battle stress comes true for overcoming of difficulties of refurbishable period with the aim of softening of the psyche injuring experiencing and successful readaptation to peaceful life.

Key words: proceeding in psychical firmness, combatant, psychical health, social-psychological rehabilitation, neuropsychic tension. 